\title{
JENIS BAKTERI DAN SENSITIVITAS ANTIBIOTIK PADA KASUS INFEKSI NOSOKOMIAL AKIBAT PEMASANGAN KATETER DI RSSA MALANG DALAM PERIODE NOVEMBER 2000 - MARET 2001
}

\section{TYPES OF BACTERIA AND THEIR SENSITIVITY TO ANTIBIOTICS IN CASES OF NOSOCOMIAL INFECTION ATTRIBUTABLE TO CATHETER INSERTION IN RSSA MALANG DURING THE PERIOD OF NOVEMBER 2000 - MARCH 2001}

\author{
Djoni Djunaedi \\ Sie Tropik Infeksi Laboratorium IImu Penyakit Dalam Fakultas Kedokteran Universitas Brawijaya Malang
}

\begin{abstract}
The incidence of Nosocomial Infection (NI) including infection of the urinary tract attributable to catheter insertion aggravates the existing conditions. Local symptoms and septis that occured could prolong hopitalization, and even caused death. So far, prevention of NI has been undertaken only through the adherence to the standard procedure. The important problem that arises is whether the prevention of NI should rely only on the adherence of the standard procedure. In order to find the solution, an appropriate investigation is called for. The materials utilized were (a) urine collected from obstetric-gynaecological patients that required catheter insertion - urine sample was taken using antiseptical procedures before and after catheter insertion within the period of $2 \times 24$ hours, (b) the end section of catheter canule when the the catheter was taken off. The materials were cultured in blood plates. Bacterial counts were performed on the data with respect to bacterial types and their sensitivity to antibiotics of the families of Cephalosporin (Cefotaxim), Aminoglycoside (Amikacin), Quinolone (Ciprofoxacine), Penicilline (Amoxicilline, Ampicilline), cotrimoxazole and Nitrofurantoin. Before catheter insertion, the urine culture was $100 \%$ negative, after catheter insertion $32 \%$ of them was positive, while $71,5 \%$ of that from the end section of the catheter canule was positive. The most prevalent bacteria found were E. coli, P. aerogenusa, and A. Anihtratus. It seems that a revised standard procedure is required in order to prevent $\mathrm{NI}$ from occuring.
\end{abstract}

Key words: NI, catheter insertion, type of bacterias, antibiotics sensitivity

\section{PENDAHULUAN}

Infeksi nosokomial (INOK) atau nosocomial infection (NI) merupakan suatu "jenis" infeksi di lingkungan rumah sakit yang diperoleh ketika pasien dirawat di rumah sakit tersebut. Belakangan, terminologi lain yang dipakai untuk menyatakan "jenis" infeksi semacam itu adalah hospital acquired infection (HAI). Kehadiran INOK baik berupa infeksi pada vena yang umumnya terjadi akibat pemasangan infus, infeksi saluran kemih yang umumnya terjadi akibat pemasangan kateter, infeksi pada luka operasi, infeksi pada saluran pernapasan maupun infeksi umbilikus pada neonatus bermuara pada memperparah kondisi penyakit yang sudah ada. Gejala yang muncul dapat berupa gejala lokal seperti phlebitis, radang lokal pada tempat operasi, radang kandung kemih dan saluran kemih pada pemasangan kateter, maupun gejala sistemik berupa sepsis yang dapat menyebabkan pada kematian $(1,2,3,4)$. Di samping itu, kehadiran INOK juga memperpanjang masa perawatan

Jurnal Kedokteran Brawijaya, Vol. XXII, No. 3, Desember 2006 Korespondensi: Djoni Djunaedi; Sie Tropik Infeksi Laboratorium IPD FK Unibraw /RSU dr. Saiful Anwar Malang; Jl. Jaksa Agung Suprapto No. 2 Malang; 0341 - 357663
$(5,6,7)$. Ini berarti, INOK memperburuk penyakit yang telah ada dan mengurangi efisiensi perawatan.

Sejauh ini, upaya yang dilakukan untuk mencegah kehadiran INOK adalah dengan memberikan antibiotik beberapa saat sebelum dilakukan tindakan operasi, namun pemberian antibiotik sebelum dilakukan pemasangan kateter pada pasien obstetri dan ginekologis umumnya tidak dikerjakan. Upaya pencegahan INOK pada tindakan pemasangan kateter hanya ditumpukan pada ketaatan cara pemasangan kateter dengan prosedur tetap (protap) yang berlaku. Masalah yang ada: (a) Apakah pemasangan kateter sesuai dengan prosedur tetap tersebut menjamin pasien dari peluang mengalami INOK dengan segala dampaknya yang sangat merugikan upaya penyembuhan pasien di samping pembengkakan dana perawatan? (b) Jika terjadi INOK akibat pemasangan kateter, bagaimana gambaran jenis bakteri penyebab INOK tersebut dan sensitifitasnya terhadap antibiotik? Untuk mengetahui hal tersebut dibutuhkan penelitian.

\section{METODE}

Bahan yang dipakai dalam penelitian ini adalah: (a) urin yang diambil dari pasien obstetri-ginelologis yang dipa- 
sang kateter dengan menggunakan cara sesuai dengan prosedur tetap pemasangan kateter yang selama ini disepakati. Urin tersebut diambil secara antiseptik pada saat sebelum dan setelah pemasangan kateter selama $2 \times 24$ jam, dan (b) potongan ujung kanul kateter pada saat kateter dilepas setelah pemasangan selama $2 \times 24$ jam. Bahanbahan tersebut kemudian dibiakkan pada media agar darah.

Jumlah pasien obstetri-ginekologis yang dilibatkan dalam penelitian ini sebesar 28 orang. Terhadap data yang diperoleh dilakukan perhitungan proporsional mengenai jumlah yang menderita INOK, jenis bakteri dan sensitivitasnya terhadap antibiotik golongan Sefalosporin (Cefotaxim), Aminoglikosida (Amikacin), Quinolone (Ciprofloxacine), Penicillin (Amoxicillin, Ampisilin), Cotrimoxazole dan Nitrofurantoin.

Inti prosedur tetap pemasangan kateter adalah sebagai berikut:

1. Melakukan persiapan berupa memberikan penjelasan mengenai maksud pemasangan kateter kepada pasien maupun keluarganya, menutup tirai ruangan pasien, mengatur penerangan ruangan secukupnya, mengatur posisi pasien - terlentang di atas tempat tidur pasien dengan kedua lutut ditekuk dan jarak kedua lutut direnggangkan, dan meletakkan troli berisi peralatan steril yang dibutuhkan untuk pemasangan kateter di dekat tempat tidur pasien.

2. Dokter atau perawat yang bertugas memasang kateter melakukan cuci tangan secara antiseptik, mengatur peralatan kateter dengan teknik antiseptik, dan memilih ukuran kateter 1 atau 2 nomor lebih kecil dari perkiraan diameter lubang uretra.

3. Dokter atau perawat yang bersangkutan kemudian memakai sarung tangan steril untuk membersihkan lubang uretra dan vulva - dengan 2 jari tangan kiri (ibu jari dan telunjuk) labia mayora dibuka sedang tangan kanan membersihkan permukaan labia mayora bagian dalam dengan menggunakan kapas savlon (satu arah dan satu sisi kemudian baru sisi yang lain) dari simfisis pubis menuju ke rektum. Selanjutnya dengan cara yang sama, labia minora dan bagian sentral vulva dibersihkan. Setelah itu, sarung tangan dilepaskan dan diganti dengan sarung tangan steril yang lain.

4. Asisten memilih kateter yang sesuai dan membukanya secara antiseptik kemudian meletakkannya di tempat steril dilanjutkan dengan meletakkan jelly pada kassa steril untuk dioleskan pada ujung kateter.

5. Setelah duk steril diletakkan di atas genetalia, labia dibuka dan ditahan dengan ibu jari dan jari telunjuk, sedang tangan lainnya memasukkan kateter ke dalam lubang uretra. Kemudian, setelah kateter masuk, suntikkan 5-10 cc aquadest untuk mengisi balon kateter. Selanjutnya, kateter difiksasi pada paha atas pasien.
Prosedur isolasi bakteri dan uji kepekaan terhadap antibiotika merujuk pada SMF Mikrobiologi Klinik di RSSA Malang

\section{HASIL PENELITIAN}

Hasil biakan urin selama kurun waktu 6 bulan di RSSA, didapatkan sejumlah 28 yang diambil dari kelompok wanita yaitu pasien obstetri-ginekologis sebelum dilakukan pemasangan kateter semuanya $(100 \%)$ menunjukkan hasil negatif. Artinya, tidak ditemukan bakteri dalam urin tersebut sebelum dilakukan pemasangan kateter. Namun, masingmasing sejumlah 9 buah (32\%) asal biakan urin dan 20 $(71,5 \%)$ asal biakan potongan ujung kanul menunjukkan hasil biakan positif yang berasal dari 28 bahan urin setelah dilakukan pemasangan kateter seperti yang ditunjukkan pada Tabel 1.

Tabel 1. Hasil biakan bahan urin yang diambil dari urin dan potongan kanul setelah 24 jam

\begin{tabular}{lccc}
\hline \multirow{2}{*}{ Asal biakan } & \multicolumn{2}{c}{ Hasil biakan } & \\
\cline { 2 - 3 }$\Sigma$ & Positif & Negatif & $\Sigma$ bahan urin \\
\hline Urin & $9(32 \%)$ & $19(68 \%)$ & 28 \\
Potongan ujung kanul $20(71,5 \%)$ & $8(38,5 \%)$ & 28 \\
\hline
\end{tabular}

Hasil biakan positif dari urine sejumlah 9 terdiri dari P. aerogenosa $4(44,5 \%)$, E. coli $2(22,2 \%)$, A. anithratus 2 $(22,2 \%)$, dan $E$. aerogenes $1(11,1 \%)$.

Sedangkan hasil biakan positif dari potongan ujung kanul sejumlah 20 terdiri dari $E$. coli $5(25 \%), P$. aerogenosa $4(20 \%)$, A. anithratus 4 (20\%), A. hydrophilia 2 (10\%), dan $P$. mirabilis, E. agglomerans, E. ginggivae, $S$. coagulase negatif, $E$. aerogenes masing-masing $1(5 \%)$. Hasil biakan ini dapat dilihat pada Tabel 2.

Tabel 2. Hasil biakan bahan urin dan potongan ujung kanul pada 28 bahan urin

\begin{tabular}{llll}
\hline \multicolumn{2}{c}{ Biakan urin positf } & \multicolumn{2}{l}{ Biakan potongan ujung kanul positif } \\
\hline Jenis bakteri & Jumlah & Jenis bakteri & Jumlah \\
\hline P. aerogenosa & $4(44,5 \%)$ & E. coli & $5(25 \%)$ \\
E. coli & $2(22,2 \%)$ & P. aerogenosa & $4(20 \%)$ \\
A. anihtratus & $2(22,2 \%)$ & A. anithratus & $4(20 \%)$ \\
E. aerogenes & $1(11,1 \%)$ & A. hydrophilia & $2(10 \%)$ \\
& & P. mirabilis & $1(5 \%)$ \\
& & E. anglomerans & $1(5 \%)$ \\
& & E. ginggivae & $1(5 \%)$ \\
& & S. coagulase negatif & $1(5 \%)$ \\
& E. aerogenes & $1(5 \%)$ \\
& E. aerogenes & $1(5 \%)$ \\
\hline
\end{tabular}

Tes sensitivitas biakan bakteri terhadap antibiotik menunjukkan hasil yang dapat dilihat pada Tabel 3 . 
Tabel 3. Jenis antibiotika yang sensitif terhadap hasil biakan bahan urin dan potongan ujung kanul

\begin{tabular}{lcccccccc}
\hline \multicolumn{1}{c}{ Bakteri } & \multicolumn{7}{c}{ Jenis Antibiotika yang Sensitif } \\
\hline \multicolumn{1}{c}{ Jenis } & $\Sigma$ & CTX & AMK & CIP & AMP & AMC & STX & F \\
\hline P. aerogenusa & 8 & $6(75 \%)$ & $8(100 \%)$ & $7(87,5 \%)$ & $1(12,5 \%)$ & $1(12,5 \%)$ & $2(25 \%)$ & $4(50 \%)$ \\
E. coli & 7 & $7(100 \%)$ & $6(86 \%)$ & $7(100 \%)$ & $3(42,8 \%)$ & $3(42,8 \%)$ & $4(57,1 \%)$ & $5(71,2 \%)$ \\
A. anitratus & 6 & $5(83,3 \%)$ & $5(83,3 \%)$ & $5(83,3 \%)$ & $0(0 \%)$ & $1(16,7 \%)$ & $1(16,7 \%)$ & $2(33,4 \%)$ \\
A. hydrophilia & 2 & $2(100 \%)$ & $2(100 \%)$ & $2(100 \%)$ & $0(0 \%)$ & $1(50 \%)$ & $0(0 \%)$ & $1(50 \%)$ \\
E. aerogenes & 2 & $1(50 \%)$ & $2(100 \%)$ & $2(100 \%)$ & $0(0 \%)$ & $0(0 \%)$ & $0(0 \%)$ & $0(0 \%)$ \\
E. anglomerans & 1 & $1(100 \%)$ & $1(100 \%)$ & $1(100 \%)$ & $0(0 \%)$ & $0(0 \%)$ & $0(0 \%)$ & $0(0 \%)$ \\
E. ginggivae & 1 & $1(100 \%)$ & $1(100 \%)$ & $1(100 \%)$ & $0(0 \%)$ & $0(0 \%)$ & $0(0 \%)$ & $0(0 \%)$ \\
P. mirabilis & 1 & $1(100 \%)$ & $1(100 \%)$ & $1(100 \%)$ & $0(0 \%)$ & $0(0 \%)$ & $0(0 \%)$ & $0(0 \%)$ \\
S.coagulase negatif & 1 & $1(100 \%)$ & $1(100 \%)$ & $1(100 \%)$ & $1(100 \%)$ & $1(100 \%)$ & $0(0 \%)$ & $0(0 \%)$ \\
Total & 29 & $25(86 \%)$ & $27(93 \%)$ & $27(93 \%)$ & $5(17 \%)$ & $5(17 \%)$ & $5(17 \%)$ & $10(34 \%)$ \\
Keterangan: CTX=Cefotaxim & AMK=Amikacin CIP=Ciprofloxacine & & & \\
& AMP= Ampicillin & AMC=Amocixylin SXT=Cotrimoxazole & & &
\end{tabular}

\section{DISKUSI}

Bertolak dari hasil penelitian sebagaimana dipaparkan didepan, nampak bahwa meskipun pemasangan kateter telah dikerjakan dengan menggunakan prosedur tetap pemasangan kateter yang selama ini disepakati, namun peluang terjadinya INOK masih tetap tinggi. Sejumlah 9 (32\%) pasien yang dilibatkan dalam penelitian ini menunjukkan hasil positif pada biakan urin yang diambil setelah pemasangan kateter selama $2 \times 24$ jam padahal hasil biakan dari urin yang diambil sebelum pemasangan kateter menunjukkan $100 \%$ negatif. Hasil yang yang lebih tinggi yaitu sejumlah 20 $(71,5 \%)$ hasil positif pada biakan potongan ujung kanul kateter pada kurun waktu yang sama yaitu 2X24 jam. Angka yang lebih tinggi ini dapat terjadi kemungkinan akibat kolonisasi dari bakteri yang terjadi pada ujung kanul kateter yang mendahului bakteriuri yaitu keadaan bakteri akan menyebar pada cairan urin yang terdapat pada kandung kemih

Angka kasus INOK yang dihasilkan dari penelitian ini dapat dibandingkan dengan penelitian lain yaitu $11,21 \%$, $23,7 \%$ dan $33,1 \%(8,9,10)$. Angka yang relatif tinggi dari hasil penelitian ini memerlukan pemikiran mengenai cara untuk menurunkannya terutama pada tingkat keamanan prosedur tetap pemasangan kateter yang selama ini disepakati dan dikerjakan.

Jika disimak secara cermat, dari langkah-langkah prosedur tetap pemasangan kateter yang sejauh ini dikerjakan, nampaknya peluang terjadinya INOK muncul dari keamanan cara membersihkan labia mayor, labia minora, dan bagian sentral vulva sebelum kateter dimasukkan ke dalam lubang uretra. Pembersihan dengan menggunakan kapas savlon dengan cara mengusapkannya secara searah sebagaimana dikerjakan nampaknya sama sekali belum menjamin terciptanya suasana aseptik di daerah tersebut. Akibatnya bakteri yang kebetulan ada di situ secara tidak sengaja terbawa oleh ujung kanul kateter. Ini berarti, diperlukan upa- ya pembersihan yang lebih menjamin terciptanya suasana aseptik di daerah sekitar lubang uretra sebelum maupun selama kateter dipasang.

Biakan bakteri dari urin maupun dari ujung kanul kateter menunjukkan jenis yang beragam dengan $E$. coli, $P$. aerogenosa, dan $A$. anithratus menempati posisi yang relatif paling banyak. Temuan ini ada kemiripan dengan penelitian oleh Aina dan Loehoeri pada tahun 1998 yaitu $P$. aerogenosa dan $E$. coli merupakan penyebab terbanyak dalam kasus infeksi saluran kemih akibat pemasangan kateter. Sebagaimana diketahui, bakteri-bakteri tersebut merupakan bakteri yang seringkali dijumpai di daerah sekitar tempat pemasangan kateter. Hal ini memperkuat argumen mengenai diperlukannya upaya pembersihan yang lebih menjamin terciptanya suasana aseptik di daerah sekitar lubang uretra. Artinya, cara pembersihan daerah sekitar tempat pemasangan kateter sebagaimana yang dicantumkan dalam protap perlu diperbaiki.

Di samping itu, pemasangan kateter umumnya tidak dikerjakan di dalam ruangan khusus dengan udara yang terjamin kebersihannya ("steril") disertai petugas terkait yang terjamin higinitasnya. Nampaknya kedua hal tersebut juga memberi kontribusi dalam munculnya INOK pasca pemasangan kateter mengingat terbuktinya peran sterilitas udara dan higinitas petugas kamar operasi terhadap kemungkinan munculnya INOK (11). Ini berarti, pemasangan kateter nampaknya perlu dikerjakan dalam ruangan khusus yang "sterilitas" udaranya terjamin.

Tes sensitivitas biakan bakteri terhadap antibiotik menunjukkan bahwa bakteri-bakteri tersebut sensitif terhadap golongan Sefalosporin (Cefotaxim), Aminoglikosida (Amikacin), Quinolone (Ciprofloxacin) dengan kisaran angka kepekaannya $86-93 \%$. Sedangkan untuk golongan lain yaitu Penicillin (Ampisilin dan Amoxicillin), cotrimoxazole dan $\mathrm{Ni}$ trofurantoin kisaran angka kepekaannya lebih rendah yaitu antara $17-34 \%$. 


\section{KESIMPULAN DAN SARAN}

1. Diperlukan protap yang lebih menjamin terciptanya suasana aseptik di daerah sekitar lubang uretra serta sterilitas udara dan higenitas petugas yang terkait dengan pemasangan kateter.
2. Peneltian yang lebih mendalam terutama mengenai jumlah bahan pemeriksaan mengingat tingginya tingkat resisitensi bakteri penyebab INOK yang ada di bagian obstretri-ginekologi terhadap antibiotik Ampicillin, Amoxicillin, Cotrimoxazole dan Nitrofurantoin.

\section{DAFTAR KEPUSTAKAAN}

1. Hapsari D, Kurniawan UK. Faktor Resiko yang Berhubungan dengan Infeksi Nosokomial pada Pasien Di Bagian Perawatan Penyakit dalam RS Cipto Mangunkusumo Jakarta 1993. Maj-kes. Masy. Ind. 1997; xxv(1): 68-71.

2. Hasbullah HT. Pengendalian Infeksi Nosokomial di RS Persahabatan Jakarta. CDK. 1993: 82: 8-12.

3. Janas, Sutoto, Punyabi HN. Bakteremia Nosokomial di Rumah Sakit Khusus Penyakit Menular. Jakarta: MKl; 1987: 37(5): 287-298.

4. Limson BM. Nosokomial infection. Med. Prog. October 1985; 17-20.

5. Djunaedi D. Comparison between 2 Methods of Sterilization in Infusion Insertion Procedure in Cases of Nosocomial Infection Manifested in Patients Admitted at the Saiful Anwar Regional General Hospital Malang during January - June, 1998. National Congress of The Indonesian Society for The Study of Tropical Medicine and Infectious Diseases. Semarang, 20-23 November 1998.

6. Djunaedi D. Jenis Bakteri dan Antibiotik yang Sesuai pada Kasus Infeksi Nosokomial yang Dipasang Infus Intravena di Unit Pavilyun RSSA Malang pada periode Januari-Juni 1999. KONAS VI PETRI, Denpasar, Bali. 2000.

7. Hasbullah HT. Prosedur Kerja Tindakan Infasif Intravena. Dalam: Standar Prosedur Kerja Pencegahan dan Pengendalian Infeksi Nosokomial Rumah Sakit Metropolitan Medical Centre Kuningan Jakarta. 1994; 33-34.

8. Amdani SK, Juwono MA. Kuman Penyebab Infeksi Nosokomial di Ruang Rawat Inap Anak RSAB Harapan Kita, 1996. KONAS III PETRI, Balikpapan, 28-30 November 1997.

9. Ratnasari N, Loehoeri S. Asymptomatic Urinary Tract Infection Patients with Diabetes Mellitus in Internal Ward dr. Sardjito General Hospital Yogyakarta. Paper presented at $4^{\text {th }}$ National Congress of The Indonesian Society for The Study of Tropical Medicine and Infectious Diseases. Semarang, 20-23 November 1998.

10. Aina N, Loehoeri S. Catheter-associated Urinary Tract Infection. Paper presented at $4^{\text {th }}$ National Congress of The Indonesian Society for The Study of Tropical Medicine and Infectious Diseases. Semarang, 20-23 November 1998.

11. Triatmodjo P. Sterilitas Udara Ruang Operasi dan Peralatan Bedah Serta Higiene Petugas Beberapa Rumah Sakit di Jakarta. CDK. 1993: 82: 21-24. 

100 Jurnal Kedokteran Brawijaya, Vol. XXII, No. 3, Desember 2006 